\title{
大正から戦後にかけての国立公園行政における 多島海景観としての松島の評価 EVALUATION OF MATSUSHIMA AS ARCHIPELAGO LANDSCAPE \\ IN ADMINISTRATION OF NATIONAL PARK FROM TAISHO ERA TO POST-WAR
}

\author{
伊 藤 弘 ${ }^{*}$
}

\section{Hiromu ITO}

\begin{abstract}
This study aims to clarify the evaluation of the ancient scenery landscape Matsushima by the National Park Administration through literature and local surveys. Matsushima was evaluated as an archipelago, but was not designated as national park even though the view of it as an archipelago is similar to that of other natural scenic areas that are designated as national parks. This is because the purpose of national parks is to find new natural scenic areas and the elements of each are evaluated individually. It can be said that Matsushima being an archipelago landscape is the basis of its qualification to be a national park.
\end{abstract}

Keywords : National Park, an angle of depression, Matsushima, GIS 国立公園，俯角，松島，GIS

\section{1. 背景と目的}

我が国日本は周知の通り四周を海に囲まれており、古来よりその 眺めを享受する場である風景地は海を中心としたものであった。多 島海は海岸における日本を代表する地形である11。その中でも宮城 県松島は古来より日本三景として知られ、名勝指定や早くから国際 観光地点に設定されるなど、宮城県における観光の拠点として成立 してきた。県は本多静六の指導のもと保安林などと連携をとった日 本で初めての地域制自然公園ともいえる県立松島公園を整備、公園 経営計画を策定し森林管理や観光ルートの設定など観光地整備に注 力してきた。県をあげての国立公園指定請願運動も行なわれてきた が、国立公園には指定されていない。三景のうち天橋立と厳島はそ れぞれ国定公園・国立公園に指定されているのに対し、松島は県立 自然公園指定にとどまっている。しかしその経緯や背景について必 ずしも明らかにされているとはいいがたい。「日本三景」自体も衰退 しているという指摘もなされており、これは現代の「風景」への関 心が変化した現れである2）。国立公園行政における松島の取り扱い を明らかにすることは、古来よりある風景地と近代以降行政によっ て新たに見出された風景地(国立公園)の関係を見出すことである。
これにより、改めて古くよりある風景地の今後の取り扱いについて 検討することが可能になろう。

多島海景観の特徴に関しては、田村剛がその特性を整理している 3)。また、瀬戸内海を対象として意味の風景から視覚の風景へと「も のの見方」が変化したことを明らかにしたもの ${ }^{4)}$ や風景を楽しむ場 でもある多島海景観の特徴を分析したもの5) 6) がある。これらは、 風景地として評価される多島海景観の特徴を示したものであり、ま た俯角のみでその特徴を示している。一方、近代的なものの見方を 制度化してきた国立公園選定に関しては、その計画思想の変遷をみ たもの ${ }^{7)}$ 8) や特定の国立公園における指定の経緯をみたもの9) があ るが、古くよりある風景地をどのように取り扱ってきたのかをみた ものはない。

本研究は、古来より風光明媚な場所として親しまれてきた宮城県 松島の、国立公園行政の中での位置付けを、国立公園の選定に関す る言説から明らかにする。調查対象時期は、最初の国立公園が検討・ 指定された大正から昭和 10 年前後までと、その後国立公園選定要 領が定まり、多くの国立公園が指定された戦後から昭和 30 年代ま でとした。また後述するように国立公園を選定するに当たって、調

\footnotetext{
* 東京大学大学院農学生命科学研究科 助教 $\cdot$ 博士 (農学)
}

Assistant Prof., Graduate School of Agricultural and Life Sciences, The University of Tokyo 
查団は多島海景観を標高の高い展望地からの地形によって規定され る眺めを、松島の同様の眺めを参考に調査している。したがって、 国立公園に指定された地域と松島における多島海景観の実際の眺め との比較から、松島の展望地からの眺めに対する評価を明らかにす る。以上より、国立公園行政における多島海景観としての松島の評 価を考察した。

\section{2. 対象}

宮城県松島（松島町）は、古くより健保名所百首・日本三景・本 朝十二朝・東遊雑記において取り扱われ、特別名勝（大正 12 年指 定）となっている。日本三景と自然公園指定の関係をみると、前述 の通り宮島は瀬戸内海国立公園、天橋立は丹後天橋立大江山国定公 園の一部に、松島は宮城県立自然公園松島に指定されている。そも そも日本三景は風光明媚というよりも珍しい眺めとして取り上げら れていたものであるが、比較的近代的な見方をしていたとされてい る ${ }^{10)}$ 古川古松軒が「東遊雑記」において他の 2 地域と比べて松島の 景勝を称える11) など視覚的にも評価されていた。また、日本で初め ての地域制公園として松島公園計画が策定された（範囲は約 9,000ha（海域含む)）12）。後述するように昭和 7 年に最初の国立公 園を指定寸るに当たり、いくつかの候補案が内務省以外の様々な主 体（本多静六・田村剛・天然記念物調查会）から提案された。松島 は、各案いずれにおいても候補地として挙げられているにも関わら ず、唯一国立公園に指定されていない。特に天然記念物調查会によ って提案された候補地は、昭和 9 年から 11 年にかけて行われた 12 の国立公園指定において採択率が 7 割であり、残りの候補地も後に 国立公園に指定されている ${ }^{13)}$ のに対し、松島のみ現在でも指定され ていない。

松島の景観の特徵である多島海景観を有する場所は、国立公園選 定の過程において「発見」されてきた。例えば瀬戸内海は田村剛や 脇水鉄五郎によって従来評価されてきた歌枕になどに基づく景観と は異なる、多島海景観が発見された。その後も同様の景観として九 十九島 (西海国立公園) や天草松島（雲仙天草国立公園、当初は天 草国定公園）などが「発見」されてきている ${ }^{14)}$ 。

本研究では展望地からの眺めを比較するに当たって、国立公園制 定初期と国政による観光の位置づけの高まりを背景に持ち、多くの 国立公園が指定された戦後（昭和 30 年） ${ }^{15}$ ) にそれぞれ国立公園に 指定された瀬戸内海国立公園（備瀬諸島）と西海国立公園（九十九 島）を比較対象地とした（表 1）。

\section{3. 方法}

\section{(1) 国立公園指定における言説}

松島の国立公園行政における位置づけを国立公園の計画思想およ び公園選定の経緯などから明らかにする。具体的には文献調查より、 主体（専門家・自治体・国・団体および世論）ごとの国立公園に関 連する文献における松島に関する言説を中心に把握し、比較する。 専門家は、国立公園行政に影響を及ぼしていた本多静六、田村剛、 脇水鉄五郎を対象とする。国は国立公園選定時の調査報告等を中心 に把握した。また、団体および世論は国立公園協会の開催したイベ ントや新聞記事などを対象とする。

(2) 展望地からの眺め
表 1 対象地

\begin{tabular}{l|r|r|r|l}
\hline & \multicolumn{1}{|c|}{ 面積(ha) } & 公園指定年 & 島の数 & 展望地の数 \\
\hline 松島 & 9,600 & 1902 & 260 & $9(4+5)$ \\
\hline 瀬戸内海 & 770,000 & 1934 & 727 & 12 \\
\hline 九十九島 & 24,000 & 1955 & 208 & 9 \\
\hline
\end{tabular}

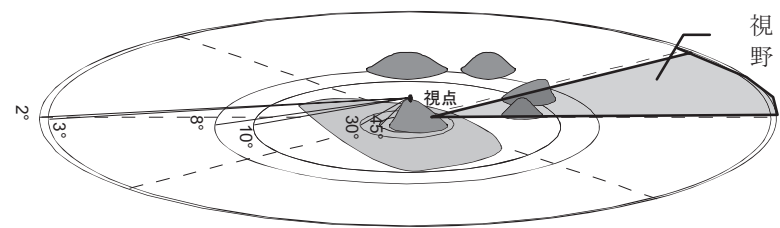

図1 展望地からの眺め（俯角と視野）

瀬戸内海などにおいては、近世までは船に乗って遊覧して風景を 楽しむいわばシークエンス景観が楽しみ方の主流であった。国立公 園指定を行うに当たっては、標高の高い展望地からその眺めを楽し むことのできるパノラマ景観が田村剛や脇水鉄五郎によって発見さ れ指定に結びついた。田村や脇水は多島海の景観は展望することを 前提 ${ }^{16 ）}$ 17) と述べており、近代以降の多島海の眺めは展望地から俯 瞰されることによって評価されてきたといえよう。また、後述する ように自然公園選定において地形によって景観類型がなされるなど 地形が重視されていた。現地調査では多島海景観は島々が海上に散 布する眺めによって評価されていたことから、既往研究も踏まえ ${ }^{18)}$ 19)、海上に出現する島々の数を分析対象とした。具体的には、俯瞰 した眺めを規定する俯角（展望地から対象までの見下ろした角度） と可視領域における島の分布を眺めの指標とした。展望地と展望地 から見える島との俯角の関係をみるために、前述の展望地からの可 視領域を俯角 $45^{\circ} 、 30^{\circ}$ (視野の下限)、1 $0^{\circ}$ (中心領域下限)、 $8^{\circ}$ (中心領域上限)、 $3^{\circ} \quad$ (視野の上限 1)、 $2^{\circ}$ （視野の上限 2$) 、 2^{\circ}$ 以下に分け、各範囲の島数を把握する。可視領域を算出するに当た っては、国土数值地図 $50 \mathrm{~m}$ メッシュマップを用いて算出した。 展望地から見える島の分布をみるために、視野を海岸線から $60^{\circ}$

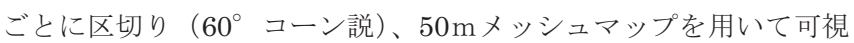
領域を決定したうえで展望地から見える島の分散を把握した(図 1 )。 展望地は、対象地において自然公園を指定する時点で評価された展 望地とした。松島では、古来より存在する展望地である四大観に加 えて公園計画において新たに 5 力所を展望地候補として揭げている。 これらは、国立公園選定における眺めと関係があるのではないかと 考え、分析対象とした (表 1 )。

\section{4．松島の位置づけと実際の眺め}

\section{(1) 大正から昭和 10 年にかけての松島に対する言説} (1)専門家

本多静六は、松島公園計画策定の指導を行った。計画対象地の範 囲を島嶼および松杉林にて囲まれる一帯とし、和歌を参照に、要素 を 1 . 名所舊蹟 2 . 船中ニテ囑望スルモノ 3 . 登山シテ展望スルモ ノと分類 ${ }^{20}$ した。また、公園計画においては松島を「(松嶋ノ) 陸 地的美タルヤ一二之レカ森林美/整否如何二關スルヤ亦論ナキ所ナ リ」と表現している。また、国立公園に関する記述において、「国立 公園とは一国の風光を代表する広大なる山川高原」と表現し、その 
候補地のひとつとして松島を挙げている ${ }^{21)}$

田村剛は、国立公園法が制定される以前、国立公園を「国土を代 表するに足る大風景」「国土国民を記念するに足る大風景」とし、国 立公園候補地として松島を挙げている ${ }^{22)}$ 。しかし、この頃候補地に 挙げられた場所は、文献により著名となった景勝地であり、広く現 地調査も行われた結果であっとはいえず、現地調查によって再検討 がなされた。実際、日本アルプスのように現地調查によって既知の 名勝であっても、新たな見方を得た場所があった ${ }^{23)}$

脇水鉄五郎は、瀬戸内海国立公園の現地調查において、その展望 地を見つけ出すための条件の一つとして「小さき島嶼が碁石を散し たやうに多数に散布するを以て多島海景観の真髄とする。陸前松島 の大高森や天草島の千厳山の眺望の如きが、その代表的のものであ る24)。」として瀬戸内海（特に備讃諸島）の展望地を抽出するにあた って、松島の眺めを規範としていた。

\section{(2)自治体}

宮城県では、人為によって荒れた景観の復興を目的として、当時 の宮城県知事（寺田祐之）による広域的な松島公園が構想された。 本計画では遊覽航路・陸路の選択および整備、森林美の整備、県営 ホテル等施設の設置が示されていた。また、国有林に地上権を設定 したり、県有地十保安林指定による管理したりするなど、現在の地 域制公園の導入を図っていた。そこでは森林計画の重要性を説き、 クロマツだけでは単調な景色になるため、主木をクロマツとし、副 木として他の樹種（桜・紅葉（ヌルデ・カエデ・ツタウルシ） を植 える、などと景観を意識した計画となっていた。また、そこで新た に従来存在していた主要な 4 ケ所の展望地（四大観）に加えて 5 ケ 所の展望地を提案していた。しかし、これら 5 ケ所の展望地は県に よる整備がなされないままその後主要な展望地とはならず、提案さ れた展望地のうち雁金森だけが一時期に展望地として認識されてい たことが絵葉書などから確認できるのみであり、その後の公園整備 は、植林の他にはパークホテルの建設や文化財の修復・電気の開設 など施設整備に偏った施策が行われた ${ }^{25)}$ 。また、1922 年に国立公園 指定請願書を提出した ${ }^{26)}$ 。

\section{(3)国}

国立公園指定に当たり、地域の観光振興を背景とした新しい風景 地の発見、及び金融恐慌を受けての外貨獲得を目指した海外からの 観光客を呼び込むための大規模な風景地という使命を果たす27）28) ために、国（厚生省、環境庁）においては、当初より松島は候補地 からはずされていた（1922）。海岸風景は瀬戸内海だけにとどまっ ており、残りは山岳になっていることや国立公園の選定要領（表 2) から考えると、恐らく山岳の雄大な景観を選定の基準としていたた め松島は候補地からはずされたと考えられる ${ }^{29)}$ 。瀬戸内海は、既往 研究でも示されているとおり、古来より和歌などで歌われてきた「意 味の風景」よりも、前述の脇水鉄五郎が探したように、現地調查に よって新たに見出された「視覚の風景」が評価され指定に至った30)。

\section{(4)団体および世論}

国立公園協会は、「我国に於ける候補地並に之れに準ずべき勝景地 の眞況を一堂の下に展示し、廣く公衆の理解に訴ふること到」を目 的に東京三越にて展示会を開催し、そこでは松島も展示された ${ }^{32}$ 。 同展示会で示された地域は、ほとんどが後に国立公園に指定されて いる。また、史蹟名勝天然記念物調查会もその趣旨や基準は不明で
表2 自然公園選定要領の変遷（景観に関連したもの）

\begin{tabular}{|c|c|}
\hline 年月日 & 選定要領・方針 \\
\hline 昭和6年 & $\begin{array}{l}\text { 第一、必要条件 } \\
\text { (一) 同一形式/風景ヨ代表シテ傑出セルコト } \\
\text { (二) 自然的風景地ニシテ其ノ区域広大ナルコト } \\
\text { (三) 地形地貌カ雄大ナルカ或八風景ガ変化ニ富ミテ美ナルコト }\end{array}$ \\
\hline $\begin{array}{c}\text { 昭和 } 27 \text { 年 } \\
1 \text { 月 } 23 \text { 日 } \\
\text { 資料 }\end{array}$ & 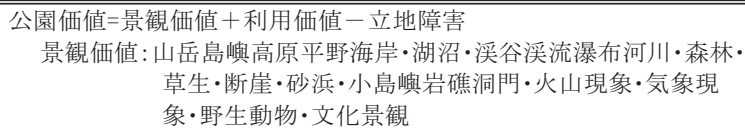 \\
\hline
\end{tabular}

利用価値: 感銘 (景観の特殊性) ・興味(利用形式の多様性、特殊

性) ・環境 (天候、保険) ・利用 (利用者数、利用施設) 立地障害:産業関係·土地関係・居住人口関係

\begin{tabular}{c|l}
\hline 昭和 27 年 & 第一要件 ${ }^{* 1}$ \\
3 月 4 日 & (1) 自然風景地を景観の特徴により夫々の風景形式に分類する
\end{tabular}

資料 (2)各風景形式毎に景観の(イ)規模(口)雄大性又は変化度(八)心理的感 銘又は科学的興味(二)人文的要素により評価を行う。

昭和 27 年

3月6日 (1)自然風景地を景観の特徵により夫々の風景形式に分類する

資料 (2)各風景形式毎に景観の(イ)規模(口)要素(八)雄大性又は変化度(二)原 始性を基礎として左の各項每に評価を行う

A 地形 B 地被 C 自然現象 (噴泉、温泉、鉱泉、噴火、動水、気象、 野生動物の出現） D 文化景観（社寺、特殊建造物、風俗、伝説、史跡 遺跡)

(3)前項の評価を地形70、地被・自然現象・文化景観を総合して30の割合 で総合評価する

(4)前項の採点により80以上国立公園候補地、60以上国定公園候補地、 30以上都道府県立自然公園候補地とする

\section{昭和 27 年 第一要件}

3月25日 (1)自然風景地を景観の特徴により夫々の風景形式に分類する

資料*2 (2)各風景形式毎に景観の(イ)規模(口)要素(八)雄大性(二)変化度(ホ)原 始性を基礎として左の各項毎 (S27.3.25資料A〜D)に評価を行う。

(3)前項の評価を地形60、地被30、自然現象及び文化景観20の割合で 総合評価する

(4)前項の採点により80以上国立公園候補地、60以上国定公園候補地、 30 以上都道府県立自然公園候補地とする

*1 昭和 27 年 3 月 4 日以降、第一要件以外はすべて同じ(第二要件:利用、第三要件:土地(所有)、

第四要件:产業、第五要件:配置、第六要件:公園区域の決定

*2この要領が、昭和 27 年 9 月に最終決定された要領となり、以降国立公園指定における基準となる

あるが、国立公園（国設公園）候補地として松島を挙げる ${ }^{33)}$ 。また、 この頃東京日日新聞と大阪毎日新聞が共催による「日本新八景」の 選定に当たっては、富士山と日本三景は別格として対象から外され

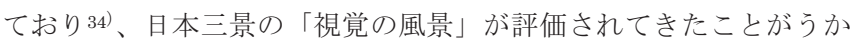
がえる。

(2) 戦後から昭和 30 年代までの松島に対する言説

\section{(1)専門家}

田村剛は、松島金華山から気仙沼にかけての範囲を国立公園の候 補地として挙げる ${ }^{35)}$ 。その後、多くの国立公園が指定される昭和 30 年直前には、「肢節の細かい軀幹海岸は最も理想的な型に属するので あるが・・・古来松島はその代表とされているが、九十九島は、こ の点では決して劣るものではなく・..」36)「(繊細な樹枝状海岸と しての景観に関して）志摩海岸の島嶼は遥かに少なく、この点は九 十九島、松島の比ではない」37) などと記述しており、松島と九十九 島の眺めを同程度、志摩海岸（英盧湾を含む）の眺めを松島より劣 るとみなしていたことがうかがえる。一方で、松島湾の水の污さお よび規模の小ささを指摘している。

脇水鉄五郎は、日本の山岳風景は外国にも多く見るべきものがあ るが、「海岸風景に至っては、日本と外国とに於て、断然非常な違ひ があり、日本の方が、数に於て遥かに多いばかりでなく、質の上で は、日本の海岸風景の方が比較にならぬほど、外国のそれに立ちま さっている。」38) とし、松島を含む日本三景は日本の海岸風景の典 型であるとしている。ただし、松島は立地が太平洋であるにもかか 
わらず、その景観としての型は日本海型であるとしている。

\section{(2)自治体}

宮城県では戦後の復興を目指して県を中心として観光行政の体制 づくり等観光事業が強力に推進され、交通・宿泊・衛生施設が整備 されていった ${ }^{39)}$ 。新たな展望地も整備されたが、その眺めに関する 検討は行われず、ただ海岸線に近いというだけで整備された40)。こ の頃整備された展望地は、松島公園計画において示された展望地候 補とは異なるものであった。また、依然として国立公園指定運動が 盛んに行われ、1947 年には三陸・金華山等とともに国立公園指定の 請願書を ${ }^{41)} 、 1957$ 年には金華山・蔵王とともに国立公園指定の請願 書を提出したのだが、いずれにおいても国立公園指定には至らなか った（三陸海岸は陸中海岸国立公園の指定を、蔵王は蔵王国定公園 の指定を、金華山は南三陸金華山国定公園の指定を受けた)。松島の 国立公園指定は松島町よりも宮城県が中心となって推し進めていた。 1962 年の自然公園指定申請箇所には松島はリス卜に入っておらず 42)、その後国立公園指定申請をしていないことがうかがえる。

\section{(3)国}

戦後も、各地で国立公園指定の陳情が行われており、候補地を選 定する作業がなされていた。1952 年には選定要件に関する基準の検 討も数回行われていた。選定を行うに当たり、基本的な考えとして 「自然公園の区域は一つの風景形式が支配する領域、即ち一つの景 観区に限定する。二つ以上の景観区を併せて一つの自然公園を構成 する場合は、景観区が近接しかつ利用上緊密な一連の関係が存し、 更に両者の評価が近似する場合に限る」としており、松島は前述の 県の働きかけとは異なり三陸や金華山・蔵王などとは分けて捉えら れることとなる ${ }^{43)}$ 。三陸や金華山と申請した際には、国は申請個所 として「三陸」とのみ記している ${ }^{44)}$ 。との要件を整理すると (表 2)、 当初は対象を総合的に捉える利用価值と対象が備えている各要素を 捉える景観価值が同等に扱われていたのに対し、次第に要素偏重と なっていった ${ }^{45}$ ことがうかがえる。具体的には、当初は心理的感銘 や科学的興味といった見る側（利用者）と見られる側（視対象）の 関係を意識した総合的な項目が設けられていたのだが、その後地形 以外の地被や自然現象・社寺および史跡遺跡等文化景観といった視 対象における要素ごとの項目が設けられていった（表 2)。さらに雄 大性に加えて変化度も独立した項目になるなど、個別化細分化した 項目に基づいた評価へと変化していった。

松島は古来霊場として存在していたが、藩政時代より観光が生業 の中心であった ${ }^{46)}$ 。そのため、環境省が評価する際の指標としてい
た社寺や史跡等文化景観は松島においては評価の対象とならず、指 定対象からはずされていった。厚生省作成の国立公園候補地解説に おいても、松島は「(古来より有名で) 一大湖水の観がある」と表現 されるにとどまっている一方、九十九島は「交通不便なため今まで あまり紹介されなかったかくれたる景勝地である。」天草は「天草の 乱等の遺跡に富み人文的にも興味が深い。」などと眺め以外の付加価 值も評価されている47)。こうして個別化細分化された指標に基づい て評価された結果、松島は国立公園候補地の対象から外れ、現地調 查も行われなかったと考えられる。一方、県が一体的に申請をして いた三陸海岸の一部は現地調查（1952）の結果、新たな景観類型 （1952）として国立公園に指定されることとなった ${ }^{48)}$ 。

西南海岸 (九十九島) 調査においては、当初は条件的に不利と目 されていたのだが、新規性と規模の大きさにより、国立公園に指定 されている ${ }^{49)}$ 。「国立公園」誌では、九十九島の解説において「(九 十九島は）同一形式の松島と共に島の密度の大きい点、島数の多い 点では我が国有数であるが、海水の清澄な点では九十九島が遥かに 優れている」「九十九島の植生は長く軍用地として保護されていた為 に比較的天然状態を示しているが、マツを主とする松島と異って常

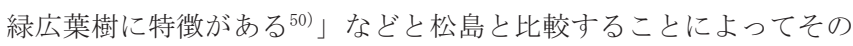
特長を示している。

\section{(4)団体および世論}

国立公園に準ずるものとして国定公園が指定されることになった ことを、一般紙は松島や天橋立などが準国立公園として指定される ことになったと報じており ${ }^{51)}$ 、世論としては日本三景と国立公園が 結び付いていたことがうかがえる。ここで「準国立公園」に指定さ れると示されているのは、松島・天橋立・白山・虹の松原・湘南三 浦半島・大沼公園・秋吉台と記している。この指定は、後に国定公 園となるが、松島はここでも対象には入っていなかった。

\section{(3) 他地域との多島海景観の比較}

\section{(1)俯角}

各地域の展望地から見える島の頻度はいずれの展望地からも概ね 100 を中心であったが、松島・四大観の頻度が最もばらつきが小さ く、瀬戸内海の頻度が最もばらつきが大きい。総計では、松島・四 大観 441、松島公園計画で新たに選定された展望地（松島公園計画） 402、瀬戸内海 1471、九十九島 1456 であり、どこの展望地でも平 均して多く島を見ることができるのは九十九島、見える島の少ない のが松島公園計画であった（図 1)。いずれの地域・展望地において も俯角 $2^{\circ}$ 以下に最も多く島を見ることができ、特に瀬戸内海の全

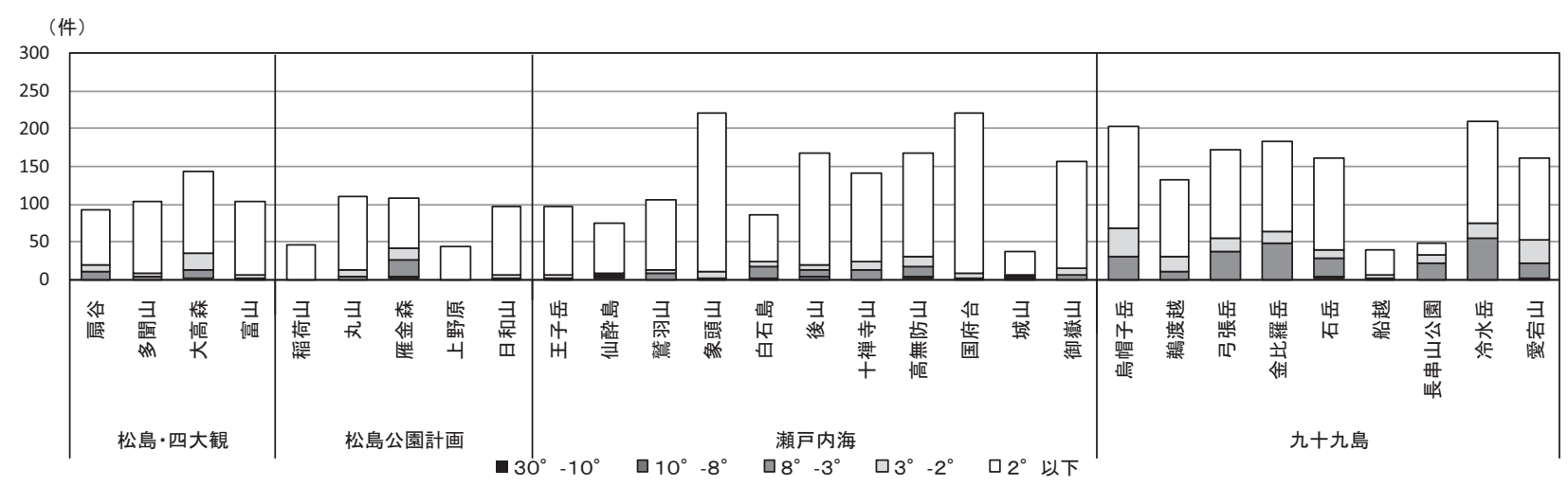

図 1 各展望地からの俯角ごとの見える島の頻度 

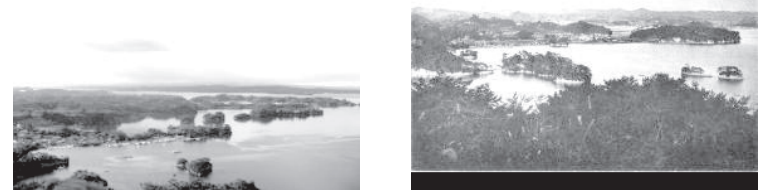

写真 1 四大観（左 : 大高森）と公園計画（右：雁金森）からの眺め 大高森：2009 年 11 月撮影、雁金森：絵葉書（撮影年不詳）

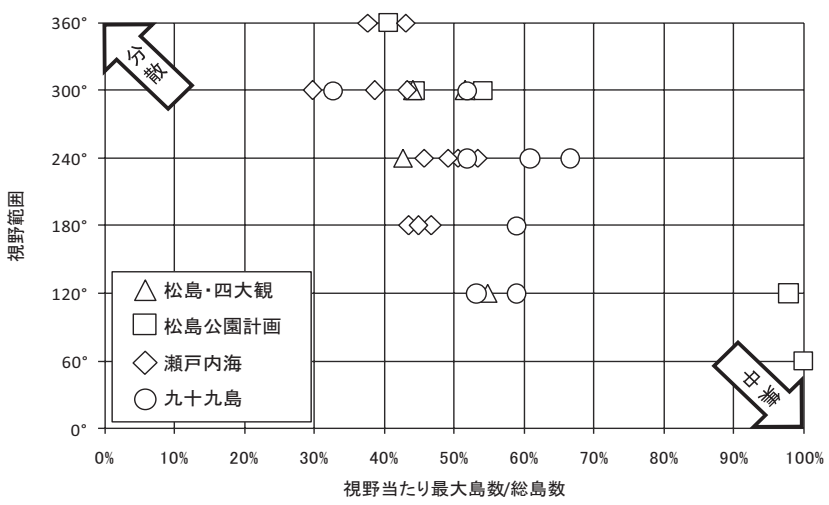

図 2 展望地から見える島の分散

ての展望地においてこの傾向が顕著にみられる。九十九島では俯角 $8^{\circ} \sim 3^{\circ} 、 3^{\circ} \sim 2^{\circ}$ の間にも他地域に比べて多く島を見ることがで きる。いずれの地域・展望地においても俯角 $8^{\circ}$ 以上には島はほと んどみえない。松島・四大観のうち前述の通り脇水鉄五郎が瀬戸内 海の展望台を探すにあたって見本とした大高森だけは $8^{\circ}$ 以下に見 える島の数も多く、松島公園計画にて提案されている雁金森からの 眺めも、大高森に近いこともあって同様の眺めをしている (写真 1 )。 (2)分布

可視領域での島の分布状況を把握するため、島が見える視野範囲 と全体の島数に占める 1 視野当たり最大島数の割合の関係をみると、 松島・四大観、瀬戸内海、九十九島は概数同じような傾向を示して おり、およそ半数の島が $60^{\circ}$ 以内で一瞥でき、その周辺およそ $180^{\circ}$ から $300^{\circ}$ の範囲に全ての島が見える。しかし、松島公園計 画にて提案された展望地からの見える島の分布は、 5 地点中 3 地点 は他の展望地とほぼ同じであるが、2 地点は他の展望地と異なりほ ぼ全ての島が一瞥して見える眺めを示しており、新たな見せ方の提 案も行っていたことがうかがえる（図 2)。

(3)眺めのタイプ $\begin{array}{lllllllllll}0 \% & 10 \% & 20 \% & 30 \% & 40 \% & 50 \% & 60 \% & 70 \% & 80 \% & 90 \% & 100 \%\end{array}$

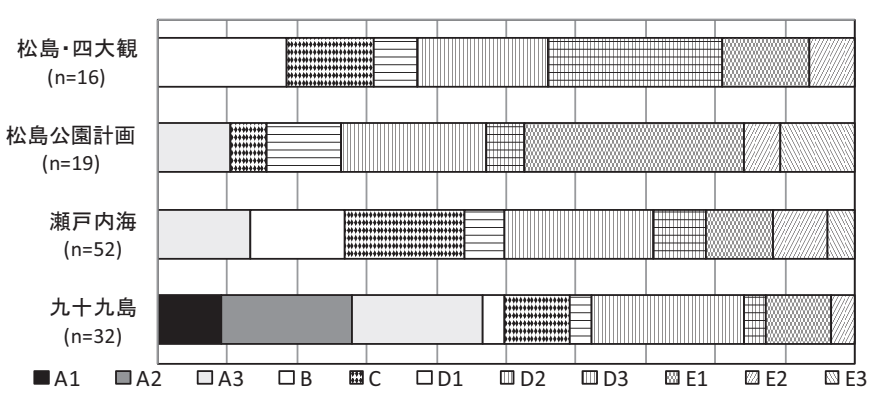

図 3 対象地ごとの島々の眺めのタイプ

各展望地の視野ごと俯角ごとに見える島の数を、全体の平均值お

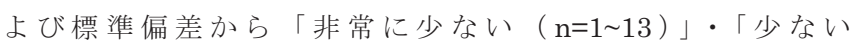

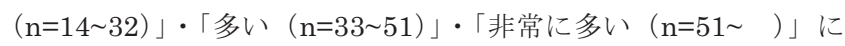
区分し、数量化 3 類およびクラスター分析を用いて展望地の視野ご とにタイプ分類した。すると、大きく $8^{\circ}$ 以下に連続して島が見え るタイプ $(\mathrm{A} 1 \cdot \mathrm{A} 2 \cdot \mathrm{A} 3) 、 8^{\circ}$ から $2^{\circ}$ の間に連続して島が見える タイプ $(\mathrm{B}) 、 3^{\circ}$ 以下に連続して島が見えるタイプ $(\mathrm{C}) 、 3^{\circ}$ から $2^{\circ}$ の間には島が見えないタイプ $(\mathrm{D} 1 \cdot \mathrm{D} 2 \cdot \mathrm{D} 3) 、 2^{\circ}$ 以下にのみ島が 見えるタイプ $(\mathrm{E} 1 \cdot \mathrm{E} 2 \cdot \mathrm{E} 3)$ に 11 分類された（表 3)。

対象地ごとのタイプの傾向をみると、松島・四大観では D3 タイ プが最も多く、次いで B タイプと D2 タイプが多い。松島公園計画 では、 $\mathrm{E} 1$ タイプが最も多く、次いで D2 タイプが多い。瀬戸内海で は D2 タイプが最も多く、Cタイプが次いで多い。九十九島では、 瀬戸内海と同様に D2 タイプが最も多く、A2 タイプと A 3 タイプが 次いで多い。以上の通り、松島公園計画以外では、 $8^{\circ}$ から連続も しくは断続的に島が見えるタイプが多いのに対し、松島公園計画で は、 $2^{\circ}$ 以下のみに島が見えるタイプが多く、眺めの分布と同様に 新しい見せ方を試みていたといえる。一方、脇水が瀬戸内海を国立 公園指定するに当たって参考にした松島・四大観の大高森からの眺 めは、 $\mathrm{B} \cdot \mathrm{C} \cdot \mathrm{D} 1 \cdot \mathrm{D} 2$ タイプとなっており、四大観の中でも瀬戸内 海や九十九島と類似している。

\section{5.まとめ}

文献調査より、明らかになったことは以下の通りである。田村剛 や脇水鉄五郎、本多静六ら専門家は松島の展望地からの眺めを高く 評価し、国立公園指定の候補地として考え、その眺めに基づいて瀬 戸内海や九十九島を見出していた。また、国立公園を世間に広める

表 3 展望地からの島々の眺めタイプ

\begin{tabular}{|c|c|c|c|c|c|c|c|c|c|c|c|}
\hline タイプ & $\mathrm{A} 1$ & $\mathrm{~A} 2$ & $\mathrm{~A} 3$ & B & $\mathrm{C}$ & D1 & D2 & D3 & E1 & $\mathrm{E} 2$ & E3 \\
\hline \multirow[b]{3}{*}{ 俯角 } & & & $\bullet$ & & •९ص & & • & $\bullet \bullet$ & ๑ & $\bullet$ & $\bullet$ \\
\hline & $\bullet$ & - & - & - & - & & & & & & \\
\hline & - & $\bullet$ & • & - & & $\bullet$ & - & - & & & \\
\hline $8^{\circ}$ & & & & & & - & & & & & \\
\hline 視野数 & & 6 & 15 & 11 & 15 & 7 & 25 & 10 & 16 & 7 & 4 \\
\hline
\end{tabular}

少ない @ やや少ない @ やや多い 
役割においても松島は貢献していたともいえる。しかし、昭和 10 年前後の最初の国立公園指定にあたっては、あくまでも新しく大規 模な風景地の発見という使命を果たすために、また昭和 30 年代の 国立公園指定にあたっては、視対象が要素ごとに個別化細分化して 評価された結果、松島は指定から漏れ、瀬戸内海や九十九島の景観 が見出され指定へとつながったといえる。展望地からの海上の島々 の眺めは瀬戸内海および九十九島と松島では類似している部分が多 く、松島における実際の眺めは評価され、それを基準とした選定が なされたといえる。また、瀬戸内海および九十九島ではさらに新た な眺めが発見され、追加されたともいえる。一方、松島公園計画で 示された新たな展望地からの眺めは他の対象地と比べて全く異なっ ており、国立公園選定において規範となる眺めを享受できる新たな 展望地の開発はできていなかった。このように、古来より風光明媚 な場所として知られてきた松島の多島海景観は、日本の景観を代表 寸る沿岸域の国立公園選定における䃈の一つとして国立公園行政に おいても評価されたといえる。松島が既に観光地化しており、また 施設中心の整備に偏り新たな眺めの提示をしなかったことにより、 現地調査されず各要素が認識されないまま、固定されたイメージに よって評価され、国立公園の選定から漏れてしまった。国立公園が 新しい風景地の発見を志向し、その目的から選に漏れたのだが、多 島海景観における眺めの一つの規範を示したという点においては、 古来よりある「日本三景」という意味づけ以外にも評価されるべき 景観であるといえよう。松島はあまりにも「視覚の風景」に特化し てきたため、今後は改めて霊場としての意味づけの再確認や本研究 で明らかになった意味づけなどを付加した新たな風景づくりが求め られるところである。

\section{参考文献}

1）建設省国土地理院：日本の典型地形 都道府県別一覧、建設省国土地理 院、p.316、1999

2）島尾新・長谷川成一：日本三景への誘い、pp.43-53、清文堂、2007

3）田村剛：わが多島海の景観を科学的に解剖する、読売新聞 1936 年 12 月 9 日 $\cdot 10$ 日朝刊、 1936

4) 西田正憲 : 瀬戸内海の発見、中公新書、1999

5）沈悦：中国杭州西湖における景観形成とその影響に関する研究、東京大 学学位請求論文、1997

6) 篠原修: 新体系土木工学 59 土木景観計画、pp.93-95、技報堂出版、1982 7) 堀繁: わが国の国立公園の計画管理の実態とその変遷に関する研究 ( I ) 一指定と保護計画一、東京大学農学部演習林報告 90、pp.97-182、1993

8）佐山浩：わが国の昭和 30 年代における国立公園指定の特徵と背景、ラ ンドスケープ研究 66 (5)、pp.397-400、2003

9）佐山浩：屋久島の国立公園指定に係る経緯と社会的背景、ランドスケー プ研究 65(5)、pp.417-420、2002

10）長谷川成一：失われた景観、pp.19-25、吉川弘文館、1996

11）古川古松軒・大藤時彦解説：東洋文庫 27 東遊雑記、p. 245 、平凡社、 1969

12）田中正大：日本の自然公園 自然保護と風景保護、pp.56-76、相模選 書、 1981

13) 村串仁三郎 : 国立公園成立史の研究一開発と自然保護の確執を中心に、 pp.42-44、法政大学出版局、2005

14）西田正憲：瀬戸内海の発見、pp.201-206、中公新書、1999

15）佐山浩：わが国の昭和 30 年代における国立公園指定の特徵と背景、ラ ンドスケープ研究 66 (5)、pp.397-400、2003

16）田村剛：わが多島海の景観を科学的に解剖する、読売新聞 1936 年 12 月 9 日、10日朝刊、 1936 17）脇水鉄五郎：日本風景誌、pp.237-238、河出書房、1939

18）篠原修：新体系土木工学 59 土木景観計画、p.94、技報堂出版、1982

19）樋口忠彦：景観の構造、pp.42-44、技報堂出版、1975

20）宮城懸内務部：松島公園経営計画、pp.17-19、1909

21）本多静六：都市と公園、p.9、成美堂書店、1924

22）田村剛：国立公園の本質、pp.7-9、庭園 3(2)、1921

23）厚生省国立公園部監修・(財) 国立公園協会編：日本の国立公園、国立 公園協会、1951

24）脇水鉄五郎：日本風景誌、pp.237-238、河出書房、1939

25）宮城懸内務部：松島公園経営報告書、1915

26）宮城懸：宮城懸史 16 観光、pp.23、（財）宮城懸史刊行会、1955

27）村串仁三郎：国立公園成立史の研究一開発と自然保護の確執を中心に、 法政大学出版局、pp.48-69、2005

28）田中正大：日本の自然公園 自然保護と風景保護、pp. 233-238、相模 選書、 1981

29）田中正大：日本の自然公園、pp.214-215、相模選書、1981

30）西田正憲：瀬戸内海の発見、pp.184-222、中公新書、1999

31）細川護立：國立公園展覧会開催に際して、国立公園 1 （6）、p.1、1929

32）細川護立：國立公園展覧会開催に際して、国立公園 1 （6）、p.5、1929

33）史蹟名勝天然記念物調查会：国説公園候補地と各府県の申請地、史蹟 名勝天然記念物 5(11) 、p.132、1922

34）東京日日新聞 1927 年 4 月 15 日広告記事、「全国注視の的 日本新八 景の選定」、 1927

35）田村剛：国立公園講話、pp.139-141、明治書院、1948

36）田村剛：世界に誇るわが海の景観、国立公園 31、p.4、1952

37）田村剛：自然公園候補地の展望、国立公園 36 - 37、p.4、1952

38）脇水鉄五郎：日本風景の研究、pp.8-18、春陽堂文庫、1943

39）宮城懸：宮城懸史 16 観光、pp.19-24、（財）宮城懸史刊行会、1955

40）松島町史編纂委員会：松島町史 通史編 II 、pp.232-233

41）金華山、松島、旭山、牡鹿半島及び本吉海岸を含む地帶を國立公園に 指定の請願、衆議院本会議、1945

42）厚生省：自然公園審議会資料、1962

43) 自然公園候補地選定特別委員会: 選定要領資料 昭和 27 年 1 月 23 日、

3 月 4 日、 3 月 6 日、 3 月 25 日、 1952

44）厚生省：自然公園審議会資料、1962

45）国立公園部：自然公園候補地の紹介、国立公園 $36 \cdot 37 、 p p .25 、 1952$

46）松島町、松島町誌、pp.229-237、1960

47) 厚生省：候補地解説、不詳

48）国立公園部：国立公園の選定、国立公園 57・58、pp.3-6、1954

49）国立公園部：自然公園候補地の紹介、国立公園 $36 \cdot 37 、$ p.4、1952

50）国立公園部：自然公園候補地の紹介、国立公園 $36 \cdot 37 、 \mathrm{pp} .46-47 、 1952$

$51 ）$ 読売新聞 1948 年 1 月 26 日朝刊記事、「松島』や『天の橋立』名勝 地七力所 準国立公園に指定、1948

（2009年11月17日原稿受理，2010年 7 月 2 日採用決定） 